\title{
NOTE ON COINAGE AND MONEYS OF ACCOUNT
}

The many systems of money of account used in the Burgundian Low Countries were generally based on pounds (livres, abbreviated $£$ ), shillings (sous, abbreviated s) and pence (deniers, abbreviated d). The most common in ducal accounts (of the receivers general) was the pound of 40 Flemish groats, the groat being a silver coin in circulation in Flanders. Unless otherwise stated, all references to pounds, shillings and pence relate to this money of account. Receivers also sometimes used a royal money of account known as the pound of Tours (livre tournois), which was generally worth 36 Flemish groats. Town accounts used these monies of account and others too. Most important for our purposes is a money of account used in Bruges, the Flemish pound (pond groot), made up of 240 Flemish groats (and therefore equivalent to 6 pounds of 40 groats). The Flemish pound of Paris (Parisis) also figures as a money of account in Bruges, and was worth 20 Flemish groats.

There were many types of coinage in circulation too, and these were subject to periodic revaluations. The gold coins mentioned in the course of this book were the écu (valued at 40 groats), the philippus or ridder (introduced by Duke Philip in 1433, and valued at 48 groats) and the florin (c.40 groats). The standard silver coins in circulation were the Flemish groat and the stuiver (valued at 2 groats). Miten were small copper coins: 24 made up a groat. After the unification of coinages of the Burgundian Netherlands in 1433, moneys of different regions were tied in fixed relation to each other (such that the pound of 40 groats was equivalent to 1.5 pounds of Brabant).

For further detail on these matters the reader may consult P. Spufford, Monetary problems and policies in the Burgundian Netherlands (1433-96) (Leiden, 1977). 